\title{
Penerapan Model Pembelajaran Quantum Teaching Learning Untuk Meningkatkan Hasil Belajar Matematika Di SMP Negeri 1 Kecamatan Deli Tua, Kabupaten Deli Serdang
}

\section{Juned}

SMP Negeri 1 Kecamatan Deli Tua, Kabupaten Deli Serdang

Corresponding Author : juned1234@gmail.com

\begin{tabular}{ll}
\hline & \multicolumn{1}{c}{ ABSTRACT } \\
\cline { 2 - 3 } & Tujuan penelitian ini untuk meningkatkan hasil belajar siswa pada \\
pembelajaran aljabar kelas VIII SMP Negeri 1 Kecamatan Deli Tua, Kabupaten \\
Deli Serdang dengan penerapan model pembelajaran quantum teaching \\
Tahun Pelajaran 2018/2019. Penelitian ini adalah penelitian tindakan kelas \\
dengan 2 siklus, setiap siklus terdiri 4 kegiatan yaitu perencanaan, tindakan, \\
observasi dan refleksi yang diikuti oleh perencanaan pada siklus berikutnya \\
dengan memanfaatkan hasil refleksi sebelumnya. Adapun rancangan solusi yang \\
dimaksud adalah tindakan berupa penggunaan strategi pembelajaran \\
quantum teaching dalam mengajarkan pokok bahasan aljabar pada siswa kelas \\
VIII SMP Negeri 1 Kecamatan Deli Tua, Kabupaten Deli Serdang sebanyak 32 \\
orang. Temuan penelitian menunjukkan pembelajaran Matematika dengan \\
penerapan strategi pembelajaran quantum teaching materi aljabar dapat \\
meningkatkan hasil belajar siswa dibuktikan dengan meningkatnya hasil belajar \\
Matematika setiap siklus yaitu dari rata-rata 64,63 menjadi rata-rata 80,72.
\end{tabular}

\section{PENDAHULUAN}

Pelajaran matematika merupakan suatu bahan kajian penelitian yang mempelajari konsep bilangan, pengukuran dan geometri, aljabar, serta pengolahan data. Selama ini, konsep-konsep matematika yang dibangun oleh guru kepada siswa tidak sesuai dengan yang dikemukakan Joyce and Weil, antara lain : (a) guru hanya melulu pada proses penalaran deduktif (kegiatan inti) tanpa memperhatikan proses penalaran induktif (karakteristik peserta didik) pada awal pembelajaran dimulai; (b) guru tidak mengetahui sejauh mana tingkat pengetahuan dasar anak didiknya sehingga begitu masuk dalam kegiatan inti, siswa semakin dijejali hal-hal yang lebih rumit; (c) ketidakmampuan guru untuk mempelajari kemampuan siswa dan memperhatikan perkembangan strategi belajarnya; (d) guru selalu menerapkan strategi pembelajaran terkesan monoton karena tidak diperkaya dengan hal-hal yang ikut melibatkan siswa dalam kegiatan pembelajaran sehingga siswa cendrung hanya menerima dan menghafal pelajaran tanpa mengetahui adanya hubungan antara pengetahuan yang diperoleh dengan aplikasi pada 
Cybernetics: Journal of Research and Educational Studies

Volume 2 Nomor 3, Juli 2021

Halaman 45-54

kehidupannya yang nyata dalam memecahkan masalah yang ada di sekitarnya. Maka muncullah anggapan bahwa belajar matematika itu tetap sulit dan tidak meyenangkan. Sanjaya (2010: 93-95) mengemukakan beberapa faktor penyebab, yaitu : (a) guru tidak berusaha untuk mengetahui kemampuan awal siswa; (b) guru tidak pernah mengajak siswa berpikir; (c) guru tidak berusaha memperoleh umpan balik; (d) guru merasa bahwa ia satu-satunya sumber belajar (learning resources) bukan sebagai pengelola pembelajaran (manager of instruction).

Dalam membelajarkan Matematika kepada siswa, guru hendaknya lebih memilih berbagai variasi pendekatan, strategi, metode yang sesuai dengan situasi sehingga tujuan pembelajaran yang direncanakan akan tercapai. Perlu diketahui bahwa baik atau tidaknya suatu pemilihan metode pembelajaran akan tergantung tujuan pembelajarannya, kesesuaian dengan materi pembelajaran, tingkat perkembangan peserta didik (siswa), kemampuan guru dalam mengelola pembelajaran serta mengoptimalkan sumber-sumber belajar yang ada.

Strategi pembelajaran memiliki andil yang cukup besar dalam kegiatan belajar mengajar. Kemampuan menangkap pelajaran oleh siswa dapat dipengaruhi dari pemilihan strategi pembelajaran yang tepat, sehingga tujuan pembelajaran yang ditetapkan akan tercapai. Terdapat berbagai macam strategi pembelajaran yang dapat dijadikan alternatif bagi guru untuk menjadikan kegiatan pembelajaran di kelas berlangsung efektif dan optimal. Salah satunya yaitu dengan menggunakan model pembelajaran quantum teaching learning. Strategi Pembelajaran Quantum Teaching memusatkan perhatian pada interaksi makna. Quantum Teaching sangat menekankan kealamiahan dan kewajaran proses pembelajaran, bukan keadaan yang dibuat-buat. Kealamiahan dan kewajaran menimbulkan suasana nyaman, segar, sehat, rileks serta santai dan menyenangkan. Untuk itu pembelajaran harus dirancang, disajikan, dikelola, difasilitasi sedemikian rupa sehingga dapat terwujud proses pembelajaran yang alamiah dan menyenangkan.

Model pembelajaran Quantum Teaching dilandasi oleh berbagai teori seperti Accelerated Learning, Multiple Intelligences, Neuro-Linguistic Programing, Experiental Learning, Cooperative Learning dan Element Effective of Instruction (Deporter, 2010). Quantum Teaching adalah model pembelajaran yang dapat membagi unsur-unsur pembelajaran menjadi dua kategori seperti konteks dan isi (Rachmawati, 2012). Kategori konteks meliputi: suasana hati, suasana lingkungan belajar yang diatur dengan baik, dasar pembelajaran, presentasi dan fasilitas. Sedangkan kategori isi meliputi: pengajar akan menemukan keterampilan bagaimana mengatakan kurikulum, pengajar akan menemukan strategi belajar yang diperlukan oleh peserta didik, yaitu: baik presentasi, fasilitas yang dinamis, keterampilan belajar untuk belajar dan keterampilan hidup (Riyanto, 2012) (Yaseer, 2014). 
Cybernetics: Journal of Research and Educational Studies

Volume 2 Nomor 3, Juli 2021

Halaman 45-54

Model Pembelajaran Quantum Teaching adalah proses belajar dengan memberikan latar belakang dan strategi untuk meningkatkan pembelajaran dan membuat proses tersebut lebih menyenangkan (Acat, 2014). Prosedur ini memberikan gaya mengajar dengan memperdayakan siswa untuk membuat siswa lebih berprestasi (Suryani, 2013). Hal ini juga membantu guru memperbesar keterampilan mengajar dan memotivasi siswa untuk giat dalam belajar, sehingga guru akhirnya mendapatkan kepuasan yang lebih besar dari karya-karya mereka (Suryani, 2013) (Acat, 2014). Keseluruhan model Quantum Teahing ini mencakup kedua teori pendidikan dan pelaksanaan di kelas dengan cepat. Model ini menggambarkan praktek dasar penelitian terpadu yang terbaik dalam dunia pendidikan dengan keseluruhan yang membuat isi pembelajaran lebih bermakna dan relevan bagi kehidupan siswa (Deporter, 2010) (Suryani, 2013) sehingga memberikan pengalaman belajar kepada siswa (Johnson, 1998) (Taber,2008).

Model Quantum Teaching memiliki kerangka desain yang dikenal sebagai singkatan TANDUR yang berarti: Tumbuhkan (tanaman untuk tumbuh), Alami (pengalaman/ menjalani), Namai (Beri nama), Demonstrasi (Menunjukkan), Ulangi (mengulang) dan Rayakan (Deslauries, 2011). Model ini memiliki beberapa prinsip dalam pembelajaran yaitu: Segalanya berbicara, Segalanya bertujuan, Pengalaman sebelum pemberian nama, Akui setiap usaha, jika layak dipelajarai maka layak pula dirayakan. Sehingga, dalam proses pembelajaran guru membuat siswa lebih aktif dalam belajar, menjadikan siswa berani dalam mengemukakan pendapat yang akan menjadikan banyak siswa unruk mencapai prestasi yang diinginkan (Deporter, 2010).

Model pembelajaran quantum teaching terjadi interaksi belajar sesuai dengan karakteristik siswa. Strategi pembelajaran quantum teaching menekankan pembelajaran yang menyenangkan sesuai dengan karakteristik siswa dan psikologis memberikan dampak positif pada usia siswa SMP yang mereka lebih senang aktif daripada hanya mendengarkan ceramah yang disampaikan guru. Dalam pelaksanaan kegiatan belajar mengajar, masih banyak guru yang mengalami kesulitan menangani kebosanan yang timbul pada diri siswa dalam hal belajar sehingga berpengaruh terhadap hasil belajar. Merujuk dari krakteristik permasalahan dalam pembelajaran Aljabar, dapat disimpulkan bahwa dengan bahwa dengan penerapan strategi pembelajaran quantum teaching learning dapat meningkatkan hasil belajar siswa pada pembelajaran Aljabar kelas VIII SMP Negeri 1 Kecamatan Deli Tua, Kabupaten Deli Serdang Kabupaten Deli Serdang 
Cybernetics: Journal of Research and Educational Studies

Volume 2 Nomor 3, Juli 2021

Halaman 45-54

\section{METODE PENELITIAN}

Penelitian ini dilaksanakan di SMP Negeri 1 Kecamatan Deli Tua, Kabupaten Deli Serdang. Subjek dalam penelitian ini adalah siswa kelas SMP Negeri 1 Kecamatan Deli Tua, Kabupaten Deli Serdang, Tahun ajaran 2016/2017. Sebanyak 32 orang. Penelitian ini adalah penelitian tindakan kelas (classroom action research), yang dirancang mengikuti Model Kemmis dan Mc Taggart dengan 2 siklus yang meliputi serangkaian yang saling terkait (berkesinambungan). Secara garis besar prosedur penelitian direncanakan menggunakan dua siklus, dimana tiap siklus mempunyai empat tahapan, yaitu: yaitu perencanaan, tindakan, observasi dan refleksi yang diikuti oleh perencanaan pada siklus berikutnya dengan memanfaatkan hasil refleksi sebelumnya.

\section{Sumber Data}

1. Siswa. Untuk mendapatkan data tentang hasil belajar.

2. Guru. Untuk melihat tingkat keberhasilan penerapan model pembelajaran Quantum Teaching.

3. Teman sejawat. Dimaksudkan sebagai sumber data untuk melihat sejauh mana keberhasilan implementasi PTK ini, baik dari sisi siswa maupun guru.

\section{Teknik dan Alat Pengumpulan Data}

Pengumpulan data dalam penelitian ini dilakukan dengan cara observasi, wawancara dan juga penggunaan tes. Bentuk tes yang digunakan adalah tes tertulis dengan bentuk instrumen tesnya adalah essai yang diberikan kepada siswa.

\section{Indikator Kinerja}

Sebagai indikator keberhasilan penelitian ini dilihat dari 2 sisi yaitu;

1. Guru Hasil observasi kinerja guru

2. Siswa Penelitian ini dikatakan berhasil jika hasil belajar siswa telah mencapai standar ketuntasan belajar perorangan bahkan melebihi standar ketuntasan belajar minimal sebesar 71 dan ketuntasan klasikal sebesar $80 \%$

\section{Analisis Data}

1. Data Kuantitatif: penelitian ini menggunakan data kuantitatif karena data penelitian berupa angka-angka yaitu teknik analisis data statistik deskriptif yang berupa hasil belajar (Sugiono, 2012:12)

2. Data Kualitatif: penelitian ini menggunakan metode data kualitatif karena proses penelitian lebih bersifat seni (kurang terpola), dan disebut sebagai metode interpretive karena data hasil penelitian lebih berkenan dengan interprestasi terhadap data yang ditemukan dilapangan (Sugiono, 2012:13). Data-data yang diperoleh dari penelitian baik lewat pengamatan, tes atau dengan menggunakan metode yang lain kemudian diolah dengan analisis 
Cybernetics: Journal of Research and Educational Studies

Volume 2 Nomor 3, Juli 2021

Halaman 45-54

deskriptif kuantitatif untuk menggambarkan peningkatan pencapaian indikator keberhasilan tiap siklus dan untuk menggambarkan keberhasilan pembelajaran dengan model pembelajaran Quantum Teaching

\section{Prosedur Penelitian}

Metode penelitian yang penulis gunakan dalam penelitian ini adalah jenis penelitian tindakan kelas (PTK). Penelitian ini dilaksanakan dengan menggunakan 2 siklus yaitu siklus 1 dan siklus 2, dimana setiap siklus terdiri dari 4 tahapan yang meliputi perencanaan, pelaksanaan tindakan, observasi dan refleksi. Siklus penelitian ini mengadopsi siklus PTK yang dikemukakan oleh Arikunto (2008:74).

\section{Siklus I}

1) Perencanaan meliputi : penyusunan Silabus, RPP, penetapan materi yang akan diterapkan dengan menggunakan model pembelajaran Quantum Teaching pada kompetensi dasar aljabar yang akan dugunakan dalam pembelajaran untuk mengetahui hasil belajar siswa.

2) Pelaksanaan tindakan meliputi : proses kegiatan pembelajaran yakni, guru melakukan proses pembelajaran dengan menggunakan model pembelajaran Quantum Teaching dan mengakhirinya dengan melakukan tes.

3) Pengamatan atau observasi, dengan melakukan pengamatan kegiatan pada saat proses pembelajaran yang meliputi aktivitas guru

4) Analisis dan refleksi adalah guru bersama dengan observer dan peneliti menyimpulkan atau menilai apakah siswa benar-benar sudah berhasil atau belum guna untuk masuk ketahap selanjutnya yaitu siklus ke II.

\section{Siklus II}

1) Perencanaan, yaitu guru membuat rencana pembelajaran berdasarkan hasil refleksi pada siklus I

2) Pelaksanaan, yaitu guru melaksanakan pembelajaran berdasarkan rencana pembelajaran yang akan dilakukan pada siklus II.

3) Pengamatan, yaitu observer dan peneliti melakukan pengamatan terhadap aktifitas pembelajaran guru

Setelah tahap perencanaan, pelaksanaan, dan pengamatan guru bersama dengan observer dan peneliti melakukan refleksi terhadap hasil belajar yang diperoleh siswa 
Cybernetics: Journal of Research and Educational Studies

Volume 2 Nomor 3, Juli 2021

Halaman 45-54

\section{HASIL DAN PEMBAHASAN}

\section{Siklus I}

Data yang didapat dari kegiatan pembelajaran pada siklus I adalah sebagai berikut

(1) Pelaksanaan pembelajaran di kelas mata pelajaran Matematika dengan menggunakan model Quantum Teaching, terlihat bahwasanya para siswa mulai antusias dan merespon positif. Mulai adanya peningkatan motivasi belajar dibandingkan pada saat pre test. Hal ini terlihat dari aktivitas bertanya siswa yang pada saat pre test mereka masih malu-malu dan takut salah, pada siklus I ini mereka sudah mulai berani bertanya meskipun bobot pertanyaannya mereka masih belum mencapai seperti yang diharapkan. Pada saat kegiatan belajar mengajar berlangsung, para siswa tampak gembira dan senang, hal ini dapat dilihat dari roman muka mereka yang tampak memancarkan semangat dan antusias untuk belajar meskipun masih ada beberapa siswa yang belum terbiasa dengan model pembelajaran,

(2) Minat dan motivasi siswa meningkat, hal ini dikarenakan siswa merasa mendapatkan penyegaran dalam kegiatan belajar mengajar, sehingga mereka berusaha memusatkan perhatian selama pembelajaran berlangsung. Akan tetapi, memasuki kegiatan penjelasan materi secara global, aktivitas siswa dalam mengajukan pertanyaan masih kurang. Hal ini dikarenakan siswa masih belum terbiasa untuk mengajukan pertanyaan. Sebaliknya, mereka lebih suka menjawab pertanyaan,

(3) hasil belajar siswa hasil evaluasi yang dilakukan guru setelah pembelajaran berlangsung, terjadi peningkatan dari test awal namun peningkatan ini belum berarti apa-apa karena rata-rata hasil belajar siswa 64,63, (6) hasil lembar observasi guru dan aktivitas siswa berada pada kategori cukup. Guru belum memberikan motivasi kepada siswa agar siswa bersemangat dalam mengikuti kegiatan pembelajaran.

Dari hasil refleksi disimpulkan bahwa untuk mencapai kualitas pembelajaran yang tinggi maka :

(1) guru menjelaskan tujuan pembelajaran pada kegiatan yang akan dilakukan

(2) Guru belum memberikan motivasi kepada siswa agar siswa bersemangat dalam mengikuti kegiatan pembelajaran. Kegiatan diskusi kelompok kurang bisa membawa siswa untuk aktif berbicara mengemukakan pendapat, bertanya dan menjawab pertanyaan,

(3) Pada waktu pertama kali pertemuan dengan diadakan pembelajaran dengan model Quantum Teching para siswa masih bingung dan merasa canggung, apalagi pada waktu mengerjakan soal awal yaitu aljabar. para siswa masih ada yang tidak senang dengan teman kelompoknya 
Cybernetics: Journal of Research and Educational Studies

Volume 2 Nomor 3, Juli 2021

Halaman 45-54

(4) Sebagian siswa mengandalkan kemampuan menjawab pertanyaan guru bukan pada kemampuan menyikapi atau memecahkan persoalan materi yang di pelajari siswa.

(5) merangkum atau menyimpulkan pelajaran sebaiknya melibatkan siswa, bukan oleh guru sendiri,

(6) guru belum mengoptimalkan variasi pembelajaran,

(7) Rata-rata siswa belum berani dan percaya diri dalam menjawab maupun menanggapi hasil diskusi dan presentasi di depan kelas.

(8) Motivasi belajar siswa terhadap matieri Matematika hanya dimiliki mereka yang sebagian besar memiliki prestasi di kelas, sedangkan mereka yang berprestasi rendah/kurang cenderung pasif dalam kegiatan belajar mengajar. Hal ini tidak terlepas dari kebiasaan siswa dalam proses belajar yang dialami sebelumnya.

Berdasarkan permasalahan yang muncul pada pelaksanaan siklus 1 yang telah diuraikan, maka hal yang perlu diperbaiki atau direvisi untuk pelaksanaan tindakan berikutnya adalah :

(1) Guru memberikan motivasi dengan lebih intensif agar siswa bersemangat mengikuti pembelajaran dan berani mempresentasikan hasil diskusi,

(2) guru mengoptimalkan penerapan strategi pembelajaran quantum teaching,

(3) guru memberikan pengarahan secara klasikal sebelum kegiatan diskusi dilaksanakan kemudian membimbing siswa dalam kelompok secara merata dan adil dalam kegiatan diskusi agar tidak ramai sendiri,

(4) pada pembelajaran tindakan sebaiknya dominasi guru agak dikurangi sehingga proses belajar mengajar lebih tampak proses belajar yang berpusat pada siswa sehingga dapat meningkatkan motivasi belajar siswa pada bidang studi Matematika,

(5) guru bersama siswa perlu meyimpulkan materi yang telah dipelajari untuk mengingatkan kembali materi yang teah dipelajari siswa.

Data yang didapat dari kegiatan pembelajaran pada siklus II adalah sebagai berikut :

(1) Guru menyampaikan materi dengan baik sehingga siswa lebih tertarik untuk mengikuti proses pembelajaran dengan strategi pembelajaran quantum teaching (terdapatnya perangkat pembelajaran RPP, silabus dan LKS).,

(2) hasil evaluasi yang dilakukan guru setelah pembelajaran berlangsung, yaitu hasil belajar siswa mengalami peningkatan yaitu rata-rata 80,72 dan siswa yang belajar tuntas $84,38 \%$

Berdasarkan hasil data terjadi peningkatan hasil belajar tetapi belum optimal, kelemahan mendasar yang ditemukan adalah masih kurangnya waktu yang ditetapkan dalam pelaksanaan pembelajaran, apalagi sebagian waktu 
Cybernetics: Journal of Research and Educational Studies

Volume 2 Nomor 3, Juli 2021

Halaman 45-54

digunakan untuk pembentukan kelompok. Pada siklus kedua ini, hampir secara keseluruhan permasalahan yang dihadapi siswa telah dapat diatasi dengan baik,

Data hasil belajar siswa, model pembelajaran quantum teaching dapat dilihat pada tabel 1 berikut ini

Tabel 1 Hasil Tes Belajar Siswa SMP Negeri 1

Kecamatan Deli Tua, Kabupaten Deli Serdang

\begin{tabular}{|c|c|c|}
\hline Hasil Test & Siklus I & Siklus II \\
\hline Skor terendah & 35 & 65 \\
\hline Skor tertinggi & 80 & 90 \\
\hline Ketuntasan & 59,38 & $84,38 \%$ \\
\hline $\begin{array}{l}\text { Rata-rata Hasil } \\
\text { belajar }\end{array}$ & 64,63 & 84,38 \\
\hline
\end{tabular}

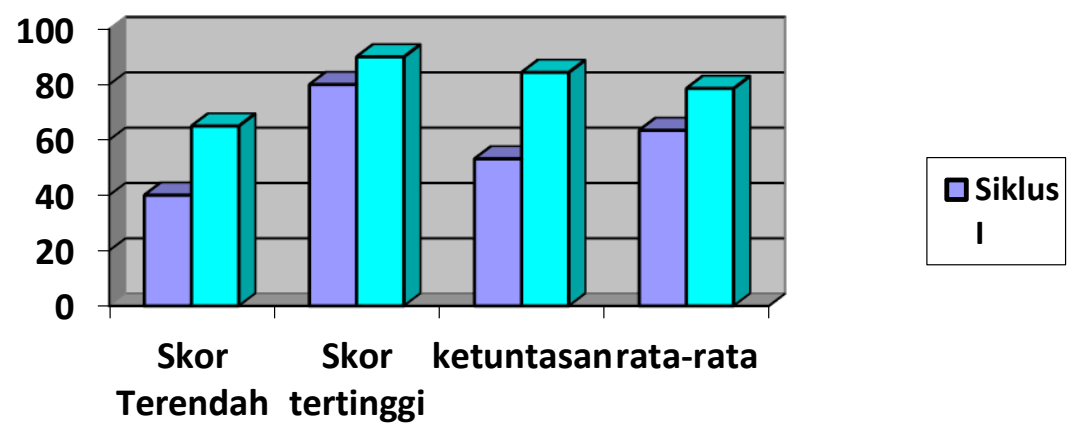

\section{Pembahasan}

\section{Gambar 1 Grafik Hasil Belajar Sisswa}

Berdasarkan analisis data yang diperoleh, terlihat bahwa hasil belajar siswa mengalami peningkatan pada mata pelajaran Matematika dengan penerapan strategi pembelajaran quantum teaching. Pembelajaran ini juga dapat memecahkan masalah yang dihadapi siswa dalam proses pembelajaran. Hal ini dimungkinkan dengan penerapan strategi pembelajaran quantum teaching menciptakan suasana belajar yang menyenangkan dan mengupayakan siswa memperoleh pengetahuan, pengalaman, penerapan dan memperoleh informasi lebih banyak dari program yang ada. penerapan metode pembelajaran quantum teaching pada proses pembelajaran Matematika mendorong siswa untul menggali kemampuannya dan menerapkannya dalam bentuk percobaan dan penerapan dalam kehidupan sehari-hari.

Berdasarkan lembar observasi guru bahwa dalam proses pembelajaran, tidak jarang rutinitas yang dilakukan guru membuat siswa jenuh dan bosan sehingga guru harus pandai-pandai menggunakan seni mengajar agar tercipta suasana pembelajaran yang lebih menyenangkan. Hal ini sesuai dengan 
pendapat Anitah (2009: 7.38) bahwa variasi adalah keanekaan yang membuat sesuatu tidak monoton, dapat berwujud perubahan-perubahan atau perbedaanperbedaan yang sengaja diciptakan/dibuat untuk kesan yang unik. Tujuan diadakannya variasi di dalam kegiatan pembelajaran adalah untuk menghilangkan kebosanan, meningkatkan minat siswa dan keingintahuan siswa, melayani gaya belajar siswa yang beragam, serta meningkatkan kadar keaktifan siswa.

Hasil belajar siswa berdasarkan pengolahan data yang telah dilaksanakan mengalami peningkatan, diperoleh fakta bahwa sebelum dilakukan tindakan dan sesudah dilakukan tindakan didapatkan perubahan rata-rata hasil belajar siswa dari setiap siklus. Hal ini bisa dilihat dari skor dasar dengan dengan ratarata kelas 39,47 dan setelah dilakukan tindakan dengan penerapan model pembelajaran Quantum Teaching hasil belajar siswa mengalami peningkatan dengan rata-rata kelas pada siklus I yaitu 64,63 meningkat dari skor dasar dengan persentase peningkatan sebesar 59,38\%. Siklus II hasil belajar siswa juga mengalami peningkatan dengan rata-rata kelas 80,72 mengalami peningkatan dengan persentase $84,38 \%$. Berdasarkan data tersebut dapat dilihat peningkatan ini terjadi karena adanya refleksi yang dilakukan disetiap akhir siklus dan siswa sudah terbiasa dengan penerapan model pembelajaran Quantum Teaching. Peningkatan hasil belajar ini juga tidak terlepas dari peran guru dalam penguasaan pembelajaran.

Peningkatan hasil belajar yang didapatkan setelah dilakukan penelitian ini dikarena pembelajaran tidak terpusat pada guru akan tetapi pembelajaran sudah terpusat pada siswa sementara guru hanya berperan sebagai fasilitator dan motivator dan interaksi antar siswa sudah mulai

\section{KESIMPULAN}

Berdasarkan hasil analisa data dan pembahasan dapat diambil kesimpulan bahwa : Pembelajaran Matematika materi aljabar dengan penerapan model pembelajaran quantum teaching learning dapat meningkatkan hasil belajar siswa kelas VIII di SMP Negeri 1 Kecamatan Deli Tua, Kabupaten Deli Serdang Kabupaten Deli Serdang.

\section{DAFTAR PUSTAKA}

Arikunto, S. 2008. Dasar - dasar Evaluasi Pendidikan (Edisi revisi), Jakarta: Bumi Aksara

Dahar, R. W. 1991. Teori- teori Belajar. Jakarta : Erlangga

DePorter, Bobbi and Mike Hernacki, Quantum Learning, New York: Dell Publishing, 2001 
Cybernetics: Journal of Research and Educational Studies

Volume 2 Nomor 3, Juli 2021

Halaman 45-54

Deporter \& Hernacki 2000. Quantum learning. Bandung. Kaifa

Gagne, Robert M. Leslie J. Briggs, and Walter W. Wager. 1992.Principles of Instructional Design. New york: Holt, Rinerhart and Winston Inc.

Hergenhahn, B.R. dan Matthew, H. Olson., (2009). Theories of Learning.Jakarta :Kencana.

Miarso (2011). Menyemai Benih Teknologi Pendidikan. Jakarta : Kencana

Munandar, S. C. U. 2004. Kreativitas dan Keberbakatan: Strategi Mewujudkan Potensi Kreatif dan Bakat. Jakarta: Grasindo

Pidarta, M. 2005. Landasan Pendidikan. Jakarta: Rianeka Cipta

Sanjaya. W. 2007. Strategi Pembelajaran Berorientasi Standart Proses Pendidikan. Jakarta: Kencana

Slavin, Robert E. (2006). Educational Psychology : Theory And Practice 8th. USA : Pearson Education, Inc.

Zaini, M. F. (2019). The Implementation Of Learning Management In Class VIII Madrasa Tsanawiyah Islamiyah (MTS) YPI Batangkuis. International Conference on Islamic Educational Management (ICIEM). https://scholar.google.co.id/citations?user=9xE516oAAAAJ\&hl=id\#d=gs_ md_cita-

$\mathrm{d} \& \mathrm{u}=\%$ 2Fcitations \%3Fview_op\%3Dview_citation\%26hl\%3Did \%26user\%3

D9xE516oAAAAJ\%26citation_for_view\%3D9xE516oAAAAJ\%3Au5HHmV D_uO8C\%26tzom\%3D-420 